\title{
EFIKASI DESTILAT KAYU NANGKA (Artocarpus integra Merr.) TERHADAP RAYAP KAYU KERING (Cryptotermes cynocephalus Light)
}

\author{
Agus Ismanto \\ Pusat Penelitian dan Pengembangan Hasil Hutan \\ Jl. Gunung Batu No. 5, Bogor \\ e-mail: ismanto-agus@yahoo.com
}

\section{ABSTRACT \\ Efficacy of jackfruit wood destilate (Artocarpus integra Merr.) against dry-wood termites (Cryptotermes cynocephalus Light)}

\begin{abstract}
Wood is organic material that is susceptible to dry wood termite attack Cryptotermes cynocephalus Light. To protect it from the attack, the wood is commonly preserved with chemicals. The chemicals preservative is not eco-friendly material. In order to explore the alternatives of preservatives, distillate extracted from jack fruit (Artocarpus integra Merr.) wood was tested against the termite. The research aimed to examine the effectiveness of distillate against termite in term of retention, termite mortality and protection degree parameter. Sample test is rubber (Hevea brasiliensis Muell.Arg.) wood with dimension $5 \mathrm{~cm} x 2,5 \mathrm{~cm}$ $x 2 \mathrm{~cm}$. Samples were soaked into distillate according to concentration i.e. 5\%; 15\%; $45 \%$ and $65 \%$ for 2 and 5 days. Experiment was designed with complete random design with 4 replications. The research showed that retention and termite mortality were positively correlated with distillate concentration whereas soak duration influenced retention. Protection degree did not differ from control. We conclude various distillate concentration influenced retention and termite mortality but not protection degree of wood.
\end{abstract}

Key words: mortality, protection degree, retention

\begin{abstract}
ABSTRAK
Kayu merupakan bahan organik yang mudah diserang oleh rayap kayu kering Cryptotermes cynocephalus Light. Untuk melindungi kayu dari serangan rayap tersebut biasanya kayu diawetkan dengan menggunakan bahan kimia sintetik. Bahan pengawet kayu termasuk bahan kimia yang tidak ramah lingkungan. Dalam rangka mencari alternatif bahan pengawet kayu ramah lingkungan, maka dicoba destilat kayu nangka (Artocarpus integra Merr.). Penelitian ini bertujuan untuk mengetahui efektivitas destilat kayu nangka terhadap retensi, mortalitas dan derajat proteksi dari serangan rayap kayu kering C. cynocephalus. Contoh uji yang digunakan adalah kayu karet (Hevea brasiliensis Muell.Arg.) dengan ukuran $5 \mathrm{~cm} \mathrm{x} \mathrm{2,5} \mathrm{cm} \mathrm{x}$ $2 \mathrm{~cm}$ yang direndam dalam cairan destilat kayu nangka dengan konsentrasi 5\%; 15\%; 45\% dan 65\% selama 2 dan 5 hari. Di samping itu disediakan contoh uji kontrol. Percobaan menggunakan Rancangan Acak Lengkap faktorial dengan 4 ulangan. Parameter yang diukur adalah retensi, mortalitas rayap kayu kering dan derajat proteksi. Hasil penelitian menunjukkan bahwa nilai retensi dan mortalitas meningkat sesuai dengan peningkatan konsentrasi. Sedangkan lama perendaman hanya berpengaruh terhadap retensi. Derajat proteksi tidak berbeda nyata antara perlakuan dengan kontrol. Kesimpulannya adalah perbedaan konsentrasi destila hanya berpengaruh terhadap retensi dan mortalitas rayap kayu kering tetapi tidak terhadap derajat proteksi.
\end{abstract}

Kata kunci: Derajat proteksi, retensi, mortalitas

\section{PENDAHULUAN}

Kayu yang terdapat di Indonesia pada umumnya memiliki keawetan alami yang rendah (kelas awet III, IV dan V) dan hanya sebagian kecil saja yang memiliki kelas keawetan tinggi (kelas awet I dan II) yaitu $15-20 \%$ (Seng
1964). Kayu sebagai bahan organik pada umumnya mudah diserang oleh organisme perusak kayu seperti serangga, jamur dan binatang laut penggerek kayu (marine borers).Akibat dari serangan organisme tersebut, maka kayu menjadi mudah rusak atau lapuk sehingga umur pakainya menjadi lebih pendek. 
Organisme yang menyebabkan tingkat kerusakan paling parah adalah rayap (Martawijaya, 1983; Duljapar, 1996; Tarumingkeng, 1971).

Kerusakan kayu bangunan akibat serangan rayap, terutama rayap kayu kering Cryptotermes cynocephalus Light. (Isoptera: Kalotermitidae) telah menyebabkan kerugi- an yang tidak sedikit. Kerugian yang terjadi akibat serangan rayap setiap tahunnya bisa mencapai milyaran rupiah. Kerugian pada bangunan perumahan di wilayah Daerah Khusus Ibukota (DKI) Jakarta Raya mencapai 8,68 triliun rupiah, sedangkan pada bangunan gedung lainnya mencapai 10 triliun rupiah pada tahun 2014 (Nandika, 2015).

Penggunaan kayu awet alamiah yang dapat menahan serangan rayap perusak kayu sampai saat ini masih sangat terbatas karena jumlahnya yang relatif sedikit dan mahal harganya. Untuk memenuhi kebutuhan kayu yang awet terhadap organisme perusak kayu khususnya rayap kayu kering, maka dilakukan upaya pengawetan kayu. Melalui usaha ini diharapkan umur pakai kayu bertambah menjadi beberapa kali lipat dan secara ekonomis dapat menguntungkan (Martawijaya, 1983).

Sampai saat kini pengawetan kayu lazimnya menggunakan bahan kimia sintetik baik anorganik maupun organik. Pengguna- an bahan pengawet tersebut selain memberi keuntungan secara ekonomis, akan tetapi juga menimbulkan dampak negatif terhadap lingkungan seperti terjadinya pencemaran lingkungan. Untuk itu perlu dicari alternatif bahan pengawet lain yang tidak memba- hayakan lingkungan dan aman bagi manusia. Salah satu alternatif yaitu dengan meman-faatkan bagian dari suatu tanaman, seperti halnya kayu nangka (Artocarpus integra Merr.). Kayu nangka apabila dibakar akan menghasilkan destilat. Destilat kayu adalah cairan yang terdiri dari pirolignat dan ter yang dihasilkan dari proses destilasi kering kayu (Ando, 1982; Komarayati \& Hendra, 1994; Hartoyo, 1977; Pari 1996).
Destilat kayu diduga dapat berfungsi sebagai insektisida karena mengandung zat fenol (Jasni \& Pari 1999). Efektivitas destilat kayu nangka untuk mencegah serangan serangga perusak kayu terutama rayap kayu kering C. cynocephalus sampai saat ini belum diketahui, oleh karena itu penelitian ini perlakukan. Penelitian ini bertujuan untuk mengetahui efikasi (daya ampuh) destilat kayu nangka (A. integra) sebagai bahan pencegah serangan rayap kayu kering C. cynocephalus.

\section{BAHAN DAN METODE}

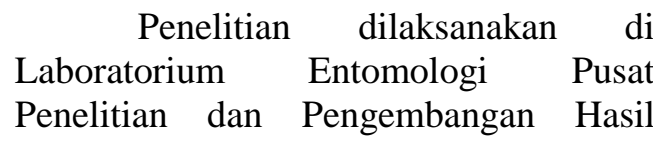
Hutan, Bogor. Bahan yang digunakan dalam penelitian ini adalah destilat kayu nangka (A. integra), rayap kayu kering $C$. cynocephalus sebagai serangga uji, kayu karet (Hevea brasiliensis Muell. Arg.) berukuran $5 \mathrm{~cm} \times 2,5 \mathrm{~cm} \times 2 \mathrm{~cm}$ sebagai kayu contoh uji dan akuades sebagai pengencer. Sedangkan alat yang digunakan adalah timbangan elektrik, kaliper, oven, pipa kaca ukuran panjang $3,5 \mathrm{~cm}$ diameter $1,8 \mathrm{~cm}$ dan lilin malam sebagai alat perekat semprong kaca pada kayu contoh uji.

Kayu contoh uji yang telah kering udara diampelas seluruh permukaannya agar halus, kemudian contoh uji tersebut di- timbang dengan menggunakan timbangan elektrik. Setelah itu, direndam dalam cairan destilat kayu nangka yang telah diencerkan dengan akuades pada konsentrasi yang berbeda yaitu 5\%; $15 \%$; $45 \%$ dan $65 \%$, masing-masing selama 2 dan 5 hari (48 dan 120 jam). Selain itu disediakan contoh uji tanpa perlakuan apapun sebagai kontrol. Contoh uji yang telah direndam kemudian dikeluarkan dari tempat rendaman dan ditiriskan beberapa saat sampai tidak menetes lagi. Selanjutnya ditimbang untuk mengukur retensi destilat kayu nangka yang masuk ke dalam kayu contoh uji, lalu dikeringanginkan di tempat yang baik aerasinya. Setelah dikering-anginkan selama 24 jam 
kemudian dimasukkan ke dalam oven pada suhu $105^{\circ} \mathrm{C}$ selama 24 jam termasuk contoh uji kontrol danselanjutnya ditimbang lagi.

Setelah semua contoh uji ditimbang,kemudian ditempel semprong kaca pada salah satu sisi terlebarnya dengan perekat lilin malam. Selanjutnya dibiarkan selama 24 jam agar lilin malam tersebut merekat kuat. Kemudian ke dalam semprong kaca tersebut dimasukkan kasta pekerja rayapkayu kering $C$. cynocephalus sebanyak 50 ekor. Setelah rayap kayu kering dimasukkan ke dalam semprong kaca yang menempel pada kayu contoh uji kemudian semprong kaca ditutup menggunakan kapas. Selanjutnya contoh uji tersebut disimpan di ruang pengujian yang gelap namun cukup aerasi selama 12 minggu. Pada akhir penelitian ditetapkan persentase mortalitas rayap kayu kering pada masing-masing contoh uji serta ditetapkan derajat proteksinya.Penelitian dianggap berhasil jika rata-rata mortalitas pada contoh uji kontrol kurang dari 50\%.

Parameter yang diukur dalam penelitian ini adalah retensi destilat kayu nangka yang masuk ke dalam kayu contoh uji, kemudian mortalitas rayap kayu kering dan derajat proteksi. Untuk menghitung mortalitas rayap kayu kering yaitu dengan cara membagi jumlah rayap kayu kering yang mati dengan jumlah rayap kayu kering awal dikalikan $100 \%$. Sedangkan untuk menentukan derajat proteksi yaitu dengan cara pemberian nilai skor (scoring) : 100 untuk contoh uji yang utuh; 90 untuk serangan rayap kayu kering yang nyata tapi hanya di permukaan saja; 70 untuk serangan yang sudah masuk tetapi belum meluas; 40 untuk serangan yang masuk dan sudah meluas serta 0 untuk contoh uji yang hancur. Untuk membandingkan nilai derajat proteksi antar berbagai perlakuan menggunakan metode statistik nonparametrik Kruskall-Wallis (Sumarni, 1988).

Penelitian ini menggunakan metode Rancangan Acak Lengkap (RAL) dengan pola faktorial $2 \times 5$, kombinasi dua faktor perlakuan, yaitu faktor A untuk lama perendaman $\left(\mathrm{a}_{1}=\right.$ perendaman 2 hari dan $\mathrm{a}_{2}=$ perendaman 5 hari) dan faktor B untuk tingkatan konsentrasi $\left[b_{1}=0 \%\right.$ (kontrol); $b_{2}=5 \%$; $\mathrm{b}_{3}=15 \% ; \mathrm{b}_{4}=45 \%$ dan $\left.\mathrm{b}_{5}=65 \%\right]$, dengan 4 kali pengulangan. Analisis data menggunakan varian (Anova) dan apabila terdapat hasil yang menunjukkan pengaruh beda nyata, maka pengujian dilanjutkan dengan uji Duncan (Gaspersz 1991).

\section{HASIL DAN PEMBAHASAN}

\section{Hasil}

\section{Retensi destilat kayu nangka}

Hasil perhitungan rata-rata retensi pada kayu contoh uji menunjukkan bahwa retensi akan meningkat sesuai dengan peningkatan konsentrasi larutan destilat kayu nangka. Rata-rata retensi terendah terdapat pada konsentrasi 5\% yaitu sebesar $0,110 \mathrm{~g} / \mathrm{cm}^{3}$ untuk perendaman selama 2 hari dan $0,133 \mathrm{~g} / \mathrm{cm}^{3}$ untuk perendaman selama 5 hari, sedangkan rata-rata retensi tertinggi terdapat pada konsentrasi $65 \%$ sebesar $1,490 \mathrm{~g} / \mathrm{cm}^{3}$ untuk perendaman 2 hari dan 1,782 $\mathrm{g} / \mathrm{cm}^{3}$ untuk perendaman 5 hari. Nilai retensi destilat kayu nangka tidak berbeda nyata untuk kedua macam lama perendaman pada konsentrasi yang sama, kecuali pada konsentrasi $45 \%$. Pada konsentrasi destilat kayu nangka 45\% menunjukkan adanya perbedaan antara perlakuan lama perendaman 2 hari dan 5 hari.

Hasil perhitungan statistik dengan analisis varian menunjukkan bahwa perlakuan konsentrasi dan lama perenda- man memperlihatkan pengaruh yang nyata terhadap nilai retensi pada tingkat kepercayaan $1 \%$, sehingga terjadi interaksi antara faktor lama perendaman dengan konsentrasi ( $\mathrm{F}$ hitung > F tabel 0,01). Hasil uji lanjut Duncan menunjukkan bahwa hanya faktor lama perendaman 2 hari dan 5 hari pada konsentrasi destilat kayu nangka $45 \%$ saja yang 
memberikan pengaruh beda nyata, sehingga terjadi interaksi antara faktor perendaman dan konsentrasi.

\section{Mortalitas rayap kayu kering}

Hasil perhitungan rata-rata mortalitas rayap kayu kering setelah 12 minggu pengumpanan menunjukkan peningkatan mortalitas rayap kayu kering sesuai dengan peningkatan konsentrasi masing-masing perlakuan. Rata-rata mortalitas rayap kayu kering pada kontrol untuk perendaman selama 2 hari dan 5 hari mencapai $16,50 \%$. Rata-rata mortalitas rayap kayu kering terendah terdapat pada konsentrasi $5 \%$ yaitu sebesar $37,50 \%$ untuk lama perendaman 2 hari dan $38 \%$ untuk lama perendaman 5 hari. Adapun rata-rata mortalitas rayap kayu kering tertinggi terdapat pada konsentrasi $65 \%$ yaitu sebesar $62 \%$ untuk perendaman selama 2 hari dan 63\% untuk perendaman selama 5 hari.

Hasil analisis varian menunjukkan bahwa perlakuan konsentrasi destilat kayu nangka memberikan pengaruh yang sangat nyata terhadap mortalitas rayap kayu kering pada tingkat kepercayaan 1\%, sedangkan lama perendaman tidak memberikan pengaruh yang nyata terhadap mortalitas rayap kayu kering. Pengujian lebih lanjut dengan uji Duncan menunjukkan adanya perbedaan yang nyata antara kontrol dengan perlakuan kosentrasi, tetapi hanya pada perlakuan konsentrasi $65 \%$ saja yang memberikan pengaruh sangat nyata.

\section{Derajat proteksi}

Hasil pengamatan secara visual terhadap kayu contoh uji setelah 12 minggu pengumpanan menunjukkan bahwa rata-rata derajat proteksi kayu contoh uji kontrol sebesar 70. Sedangkan nilai rata-rata derajat proteksi pada contoh uji yang mendapat perlakuan dengan berbagai macam konsentrasi destilat kayu nangka $(5 \% ; 15 \%$; $45 \%$; 65\%) serta lamanya perendaman (2 hari; 5 hari) juga sebesar 70 .

\section{Pembahasan}

\section{Retensi destilat kayu nangka}

Retensi adalah besarnya jumlah larutan destilat kayu nangka yang diserap oleh contoh uji kayu dengan satuan $\mathrm{g} / \mathrm{cm}^{3}$ (Hunt \& Garrat 1986). Retensi kayu contoh uji pada konsentrasi tinggi $(65 \%)$ nilainya juga tinggi. Sebaliknya pada konsentrasi rendah $(5 \%)$ nilai retensinya juga rendah. Hal ini sesuai dengan pernyataan Hunt \& Garrat (1986), bahwa besarnya nilai retensi dapat ditingkatkan dengan memperbesar konsentrasi bahan pengawet. Pada pengawetan kayu dengan proses perendaman dingin, retensi yang ideal adalah $8 \mathrm{~kg} / \mathrm{m}^{3}$ (Anonim, 1962 dalam Barly \& Lelana 2010)

\section{Mortalitas rayap kayu kering}

Mortalitas rayap kering disebabkan karena kandungan racun yang terdapat pada destilat kayu nangka yang diaplikasi- kan pada contoh uji tersebut, dengan kondisi bahan makan tunggal dan terpaksa (uji paksa). Pada mulanya rayap akan menyesuaikan diri dengan lingkungannya, kemudian mulai makan contoh uji yang telah diaplikasikan dengan konsentrasi berbeda. Jika rayap tetap tidak menemukan bagian kayu yang dapat dimakan, maka rayap tersebut akan berpuasa sampai melemah dan mati (Sumarni, 1988). Rayap-rayap yang lemah atau sakit akan dibunuh dan dimakan oleh rayap yang lebih aktif dan sehat, karena rayap mempunyai sifat kanibalisme, yaitu suatu sifat untuk memakan individu sejenis yang lemah atau sakit. Selain itu rayap juga mempunyai sifat necrofagi yaitu, memakan bangkai sesamanya (Tarumingkeng, 1971). Semakin tinggi konsentrasi destilat, maka semakin tinggi pula senyawa beracun yang terdapat pada kayu contoh, sehingga mortalitasnya pun semakin tinggi (Jasni \& Pari, 1999). 


\section{Derajat proteksi}

Derajat proteksi adalah kemampuan suatu bahan pengawet kayu (pestisida) untuk mencegah serangan organisme perusak kayu seperti antara lain rayap kayu kering. Semakin tinggi nilai derajat proteksi, semakin tinggi pula keampuhan suatu bahan pengawet kayu untuk mencegah serangan rayap kayu kering.

Berdasarkan hasil pengamatan secara visual terhadap contoh uji, maka besarnya derajat proteksi antara kontrol dan perlakuan tidak berbeda nyata yaitu 70. Artinya adalah serangan tergolong sedang, serangan baru masuk ke dalam contoh uji tetapi belum meluas. Hal ini menunjukkan bahwa semua perlakuan (sampai konsentrasi 60\%) belum dapat menahan serangan rayap (Sumarni, 1988).

\section{KESIMPULAN}

Destilat kayu nangka (A. integra Merr.) pada konsentrasi $65 \%$ dan lama perendaman 2 hari terbukti efektif membunuh rayap kayu kering $C$. cynocephalus Light. Konsentrasi destilat kayu nangka $65 \%$ dan lama perendaman 2 hari merupakan kombinasi perlakuan yang paling optimal untuk mencegah serangan rayap kayu kering $C$. cynocephalus.

\section{UCAPAN TERIMAKASIH}

Penulis mengucapkan terimakasih kepada Bapak Harhar Sugiharta Jayadikara dan ibu Dra. Moerfiah, MSi pengajar pada jurusan Biologi, Fakultas MIPA, Universitas Pakuan, Bogor yang telah memberikan masukan dalam penulisan naskah ini.

\section{DAFTAR PUSTAKA}

Ando, Y. 1982. Hasil destilasi kering beberapa jenis kayu Indonesia. Laporan No. 161. LPHH. Bogor.
Barly \& Lelana, NE. 2010. Pengaruh ketebalan kayu, konsentrasi larutan dan lama perendaman terhadap hasil pengawetan kayu. Jurnal Penelitian Hasil Hutan Vol. 28(1). Hal 1-8.

Duljapar, K.1996. Pengawetan kayu. Penebar Swadaya. Jakarta.

Gaspersz, V. 1991. Metode perancangan percobaan. Amrico. Bandung.

Hartoyo. 1977. Gasification of charcoal in fluidized bed for manufacturing active carbon, Report No. 98. Forest Products Research Institute.

Hunt, GM \& Garrat, GA. 1986. Pengawetan kayu. Akademika Pressindo. Jakarta.

Jasni \& Pari, G. 1999. Ter dan destilat kayu jati sebagai pencegah rayap kayu kering (Cryptotermes cynocephalus Light). Prosiding seminar peranan entomologi dalam pengendalian hama ramah lingkungan dan ekonomis. Balittro. Bogor. pp. 373-380.

Komarayati, S \& Hendra, D. 1994. Hasil destilasi kering dan nilai kalor kayu nangka (Artocarpus heterophyllus Lamk). Jurnal Penelitian Hasil Hutan Vol. 12(2). Hal 39-41.

Martawijaya, A. 1983. Keawetan beberapa jenis kayu Dipterocarpaceae. Prosiding pertemuan ilmiah pengawetan kayu. Pusat Litbang Hasil Hutan. Bogor.

Nandika, D. 2015. Waspada, 5 daerah di Jakarta rawan seranga rayap, workshop "mitigasi bahaya seranga rayap pada bangunan gedung". Diakses 26 mei 2015. http://www.Republika.co.id.

Pari, G. 1996. Hasil destilasi kering sembilan jenis kayu dari Maluku Utara. Buletin Penelitian Hasil Hutan Vol. 14(10). Hal 462-466 
Seng, OD. 1964. Berat jenis dari jenisjenis kayu indonesia dan pengertian beratnya kayu untuk keperluan praktek, Pengumuman No. 2. LPHH. Bogor.

Sumarni, G. 1988. Pengaruh kelembaban terhadap intensitas serangan, aktivitas makan dan daya hidup Cryptotermes cynocephalus Light. Jurnal Penelitian Hasil Hutan Vol. 5(4). Hal 177-178.

Tarumingkeng, RC. 1971. Biologi dan pengenalan rayap perusak kayu di Indonesia. Laporan No. 138. LPHH. Bogor. 


\section{LAMPIRAN}

\section{DAFTAR TABEL}

Tabel 1. Rata-rata retensi destilat kayu nangka

\begin{tabular}{crrrrrrrr}
\hline $\begin{array}{c}\text { Lama perendaman } \\
\text { (hari) }\end{array}$ & \multicolumn{8}{c}{ Rata-rata retensi (g/cm3) pada konsentrasi } \\
& \multicolumn{1}{c}{$5 \%$} & $15 \%$ & $45 \%$ & $65 \%$ & \\
\cline { 2 - 9 } & 0.11 & $\mathrm{a}$ & 0.335 & $\mathrm{~b}$ & 1.076 & $\mathrm{c}$ & 1.49 & $\mathrm{e}$ \\
\hline 2 & 0.133 & $\mathrm{a}$ & 0.475 & $\mathrm{~b}$ & 1.275 & $\mathrm{~d}$ & 1.782 & $\mathrm{e}$ \\
\hline
\end{tabular}

Keterangan:

Nilai dengan huruf yang berbeda pada kolom yang sama menunjukkan adanya pengaruh berbeda nyata $(\mathrm{P}<0.05)$

Tabel 2. Rata-rata mortalitas rayap setelah 12 minggu pengumpanan

\begin{tabular}{|c|c|c|c|c|c|c|c|c|}
\hline \multirow{2}{*}{$\begin{array}{l}\text { Lama perendaman } \\
\text { (hari) }\end{array}$} & \multicolumn{8}{|c|}{ Rata-rata retensi $(\mathrm{g} / \mathrm{cm} 3)$ pada konsentrasi } \\
\hline & Kontrol & $5 \%$ & & $15 \%$ & & $45 \%$ & & $65 \%$ \\
\hline 2 & $16.5 \mathrm{a}$ & 37.5 & $\mathrm{~b}$ & 40 & $\mathrm{c}$ & 42 & $\mathrm{c}$ & 62 \\
\hline 5 & $16.5 \quad \mathrm{a}$ & 38 & $\mathrm{~b}$ & 40.5 & $\mathrm{c}$ & 42.5 & $\mathrm{c}$ & 63 \\
\hline
\end{tabular}

Keterangan:

Nilai dengan huruf yang sama pada kolom yang sama menunjukkan tidak berbeda nyata $(\mathrm{P}<0.05)$

Tabel 3. Rata-rata derajat proteksi kayu nangka

\begin{tabular}{cccl}
\hline $\begin{array}{c}\text { Perendaman } \\
\text { (hari) }\end{array}$ & $\begin{array}{c}\text { Konsentrasi } \\
(\%)\end{array}$ & $\begin{array}{c}\text { Derajat } \\
\text { proteksi }\end{array}$ & \multicolumn{1}{c}{ Kondisi contoh uji } \\
\hline & kontrol & 70 & Serangan masuk ke dalam kayu tapi belum meluas \\
\hline 2 & 5 & 70 & Serangan masuk ke dalam kayu tapi belum meluas \\
& 15 & 70 & Serangan masuk ke dalam kayu tapi belum meluas \\
& 45 & 70 & Serangan masuk ke dalam kayu tapi belum meluas \\
& 65 & 70 & Serangan masuk ke dalam kayu tapi belum meluas \\
\hline 5 & 5 & 70 & Serangan masuk ke dalam kayu tapi belum meluas \\
& 15 & 70 & Serangan masuk ke dalam kayu tapi belum meluas \\
& 45 & 70 & Serangan masuk ke dalam kayu tapi belum meluas \\
& 65 & 70 & Serangan masuk ke dalam kayu tapi belum meluas \\
\hline
\end{tabular}

